\title{
MBD2 and MBD3: elusive functions and mechanisms
}

\section{Roberta Menafra and Hendrik G. Stunnenberg*}

Department of Molecular Biology, Radboud University, Nijmegen, Netherlands

\author{
Edited by: \\ Huabing Li, Yale University School of \\ Medicine, USA

\section{Reviewed by:} \\ Chris Anthony Murgatroyd, \\ Manchester Metropolitan University, \\ UK \\ Pao-Yang Chen, Academia Sinica, \\ Taiwan \\ *Correspondence: \\ Hendrik G. Stunnenberg, Department \\ of Molecular Biology, Radboud \\ University, 6525 GA Nijmegen, \\ Netherlands \\ e-mail: h.stunnenberg@ncm/s.ru.nl
}

\begin{abstract}
Deoxyribonucleic acid methylation is a long known epigenetic mark involved in many biological processes and the 'readers' of this mark belong to several distinct protein families that 'read' and 'translate' the methylation mark into a function. Methyl-CpG binding domain proteins belong to one of these families that are associated with transcriptional activation/repression, regulation of chromatin structure, pluripotency, development, and differentiation. Discovered decades ago, the systematic determination of the genomic binding sites of these readers and their epigenome make-up at a genome-wide level revealed the tip of the functional iceberg. This review focuses on two members of the methyl binding proteins, namely MBD2 and MBD3 that reside in very similar complexes, yet appear to have very different biological roles. We provide a comprehensive comparison of their genome-wide binding features and emerging roles in gene regulation.
\end{abstract}

Keywords: DNA methylation, methyl-CpG binding domain proteins, MBD2, MBD3, transcription regulation, chromatin immunoprecipitation

\section{INTRODUCTION DNA METHYLATION}

DNA methylation of cytosine residues was reported to be involved in gene silencing as early as 1975 (Holliday and Pugh, 1975; Holliday, 1989) and represents the first epigenetic mark (Holliday, 1989). In mammals, the predominant form is cytosine methylation $(5 \mathrm{mC})$ found within the context of paired symmetrical methylation at $\mathrm{CpG}$ dinucleotides. In mammalian genomes, around 70\% of CpG dinucleotides are methylated (Robertson and Jones, 2000), however, CpG islands (CGIs) - regions of local high CpG density - are mainly unmethylated. CGIs constitute around $60 \%$ of human promoters (Bird, 1986). Methylation of CGI promoters results in transcriptional silencing, for example during genomic imprinting and X-chromosome inactivation (Feinberg and Vogelstein, 1983; Ariel et al., 1995; Wutz et al., 1997). For many years, DNA methylation has been regarded as long lasting and an epigenetic lock on transcription. Cases of highly dynamic regulation of DNA methylation were reported by the Gannon and Reid laboratories (Kangaspeska et al., 2008; Metivier et al., 2008), suggesting cyclical methylation/demethylation at promoters as a part of the transcription cycle at least at some promoters. They showed that the process involves DNA methyltransferases (DNMTs) as well as thymine-DNA-glycosylase (Tdg). The recently discovered active DNA-demethylation pathway involves ten-eleven translocation (Tet) enzymes (Kriaucionis and Heintz, 2009; Tahiliani et al., 2009; Cortellino et al., 2011). Tet enzymes catalyze conversion of $5 \mathrm{mC}$ to 5 -hydroxymethylcytosine $(5 \mathrm{hmC})$ and can further oxidize $5 \mathrm{hmC}$ to 5 -formylcytosine (5fC) and 5-carboxylcytosine $(5 \mathrm{caC})$. Tdg can excise the latter two derivatives through baseexcision-repair process that will generate un-methylated cytosines (Cortellino et al., 2011; He et al., 2011; Ito et al., 2011) closing the methylation cycle. The breakthrough discovery that Tet enzymes can oxidize 5-methylcytosine has revolutionized the concepts in the epigenetic field in general and the DNA methylation field in particular.

\section{DNA-METHYLATION AND ITS READERS}

The relationship between DNA methylation and transcriptional silencing has proven challenging to decipher. Essentially, two types of mechanisms have been put forward: in the first a methylated cytosine physically inhibits binding of transcriptional regulators. It was reported that the binding of transcription factors such as AP2 (Comb and Goodman, 1990), c-Myc (Prendergast et al., 1991), NF-kB (Bednarik et al., 1991), E2F1 (Kovesdi et al., 1987), and CREB (Iguchi-Ariga and Schaffner, 1989), is affected by DNA methylation.

The prevalent model proposes that proteins bind directly to methylated DNA - the so-called readers - recruit co-repressor complexes (Klose and Bird, 2006) and trigger the formation of repressive chromatin. Methylated DNA readers fall into three main classes: (i) proteins containing a methyl-CpG-binding domain (MBD), (ii) Kaiso and Kaiso-like family of proteins including ZBTB4-33-38, characterized by the presence of BTB/POZ domain and several Kruppel-like $\mathrm{C} 2 \mathrm{H} 2$ zinc fingers, and (iii) SRA (SET and RING finger associated) domain containing proteins, like UHRF1 and UHRF2 characterized by the SRA domain that recognizes methylated DNA. Recently, a DNA pull-down screen followed by Mass Spectrometry has uncovered additional $5 \mathrm{mC}$ and $5 \mathrm{hmC}$ readers that do not belong to any of the three families listed above (Spruijt et al., 2013), such as some homeobox and Rfx proteins.

\section{THE MBD FAMILY OF PROTEINS}

The founding member of the MBD family is MeCP2 (Lewis et al., 1992), a protein of $53 \mathrm{kDa}$ containing an $\mathrm{N}$-terminal MBD (Lewis et al., 1992; Nan et al., 1993) and a C-terminal transcription repression domain (TRD; Nan et al., 1998). MeCP2 is ubiquitously expressed and highly abundant in the brain. Mutations in the gene encoding MeCP2 cause the Rett syndrome (Amir et al., 1999) and other neurodevelopmental disorders (Moretti and Zoghbi, 2006). Crystal structure of the MBD domain, in complex with 
methylated DNA, showed that it binds symmetrical methylated $\mathrm{CpGs}$ in vitro. The MBD domain of MeCP2 - a domain of 70 amino acids - has been used in homology searches that led to the identification of six additional family members named MBD1 to MBD6 (Figure 1; Hendrich and Bird, 1998). Other studies revealed four additional proteins that contain an MBD-like domain namely SETDB1, SETDB2 (Schultz et al., 2002), BAZ2A and BAZ2B (Jones et al., 2000),

$\mathrm{MBD} 1, \mathrm{MBD} 2$, and MBD4 can bind methylated DNA in vitro, while MBD3, MBD5, and MBD6 do not appear to bind methylated DNA, at least not in vitro (Laget et al., 2010). A recent study on MBD5 and MBD6 revealed that their MBD domains interact with the human PR-DUB complex (Baymaz et al., 2014). MBD1, MBD2, MeCP2, and Kaiso appear not to be essential for development since their deletion is not embryonic lethal whereas MBD3 plays an essential role in embryonic development (Hendrich et al., 2001a; Martin Caballero et al., 2009).

MBD2 and MBD3 are close relatives and probably descend via gene duplication from an ancestral MBD2/MBD3, that is present in some metazoans as for instance Caenorhabditis elegans and Drosophila (Marhold et al., 2004). Outside the MBD domain, MBD2 and MBD3 share almost $80 \%$ homology; they both have an MBD and a coiled-coil domain (CC). Apart from this common domain, MBD2 contains an additional N-terminal glycine-arginine (GR) rich domain and a transcriptional repressor domain (TRD), whereas MBD3 has a C-terminal poly-glutamate region. Three isoforms have been described for MBD2 protein: the full length MBD2a, MBD2b lacking the N-terminal GR repeat and $\mathrm{MBD} 2 \mathrm{c}$ that is a testis specific isoform lacking the $\mathrm{C}$-terminus. Also MBD3 presents three isoforms: Mbd3b - the major isoform in embryonic stem cells, Mbd3a and a smaller isoform Mbd3c (Kaji et al., 2006). The crucial difference between MBD2 and MBD3 is that MBD3 does not bind methylated DNA, because it lacks four conserved amino acids in the MBD domain.

\section{MBD PROTEIN COMPLEXES: LOOKING FOR FUNCTIONS}

Biochemical data provided strong evidence that methyl-CpGbinding domain proteins (MBPs) are an integral part of chromatin-remodeling complexes reported to mediate heterochromatin formation and transcriptional silencing. MeCP2

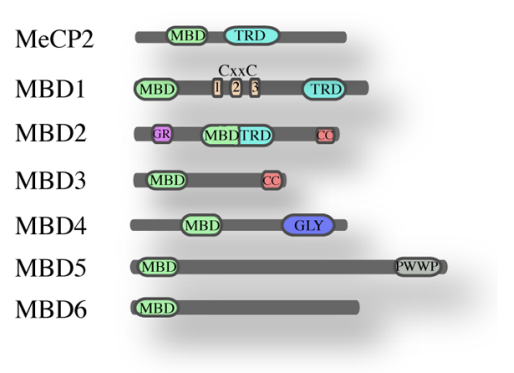

FIGURE 1 | The MBD family of proteins. Schematic overview of the mammalian MBD family and their known domains (MBD, methyl-CpG-binding domain; TRD, transcriptional repression domain; CXXC, Zinc finger-Cys- $x-x-C y s$ domain; $G / R$, arginine-rich; CC, coiled-coil; GLY, glycosylase; PWWP, Pro-Trp-Trp-Pro). transiently interacts with the Sin3A and HDAC2 complexes (Nan et al., 1998), and MBD1 with SETDB1, SUV39H, and HP1 (Fujita et al., 2003; Sarraf and Stancheva, 2004). MBD2 and MBD3 are integral parts of the Mi-2/NuRD complex (Zhang et al., 1999; Le Guezennec et al., 2006). Mi-2/NuRD complex is containing ATP-driven chromatin remodeling and histone deacetylase activities. Protein interaction studies have demonstrated that MBD2 and MBD3 bind HDAC1/2 (Wade et al., 1999; Zhang et al., 1999), GATAD2A (p66 $)$ ) and GATAD2B (p663; Brackertz et al., 2002; Saito and Ishikawa, 2002; Gnanapragasam et al., 2011). Initially MBD2 and MBD3 were thought to be part of the same complex. It was postulated that Mi-2/NuRD containing both MBD2 and MBD3 is recruited to methylated DNA via MBD2 (Zhang et al., 1999). Knockout studies however showed that MBD2 and MBD3 have distinct functions because MBD3, but not MBD2, is embryonic lethal (Hendrich et al., 2001b). Indeed biochemical analyses showed that MBD3 and MBD2 are mutually exclusive within the Mi-2/NuRD complex (Le Guezennec et al., 2006). In addition to the already known Mi-2/NuRD components, DOC1 was identified as a novel subunit of both MBD2-NuRD (Le Guezennec et al., 2006; Spruijt et al., 2010) and MBD3-NuRD (Spruijt et al., 2013).

\section{MBD PROTEINS IN TRANSCRIPTION REGULATION}

The role of MBPs in transcription regulation has been widely studied. MBPs have often been associated with transcriptional repression because of their interaction with co-repressor complexes triggering heterochromatin formation. However, a unifying role and mechanism have yet to be established. Informative approaches to decipher the function of a protein are knock-down (KD), knock-out (KO), and overexpression studies. Surprisingly, knock-down as well as overexpression of MeCP2 have been reported to cause both transcription activation and repression in the hypothalamus, with $85 \%$ of target genes being activated by MeCP2 (Chahrour et al., 2008). Also the KD of MBD2 resulted in both transcriptional activation and repression. For instance it has been shown that in adult erythrocytes, MBD2 and MTA2 - a Mi-2/NuRD subunit - are enriched at the inactive $\rho$-globin gene when this gene is highly methylated and repressed. MBD2 KD resulted in re-expression of the $\rho$-globin gene (Kransdorf et al., 2006). Another direct target of MBD2mediated repression is the Il4 gene, whose level of expression is increased in T cells derived from Mbd2-null mice (Hutchins et al., 2002). MBD2 was also reported to affect the Xist gene silencing in mouse: Mbd2 knock-down cells display lower level reactivation of Xist whereas silencing was rescued by re-expression of Mbd2 (Barr et al., 2007).

In a recent study, the link between MBD2 binding and expression changes of neighboring genes was assessed using chromatin immunoprecipitation (ChIP) experiments following MBD2 depletion (Günther et al., 2013). Only mild alterations in gene expression were observed. Moreover, after MBD2 depletion, gene expression changes revealed a roughly equal number of genes that were up or down-regulated. As mentioned above, the level of DNA methylation nor imprinting are affected in MBD2 null mice suggesting that it is not required for correct silencing of imprinted genes. 
Taken together, the generally accepted model of MBD2 acting as a transcriptional repressor has not been unambiguously supported by experimental data and a unifying model of the molecular mechanism is missing.

\section{MBD2 AND MBD3: THE COMPLEX BALANCE OF PLURIPOTENCY/REPROGRAMMING}

MBD2 has two isoforms: the full length MBD2a and a testis specific isoform $\mathrm{MBD} 2 \mathrm{c}$, lacking the C-term (Hendrich and Bird, 1998). The C-term domain of MBD2 is responsible for the interaction with p66 $\alpha$ (GATAD2A) and therefore with the Mi2-NuRD complex (Brackertz et al., 2002; Gnanapragasam et al., 2011). Protein interaction studies have shown that MBD2c is unable to bind Mi-2/NuRD components such as Mi-2 $\beta$, HDAC1 and HDAC2 (Baubec etal., 2013). A recent study showed that in human pluripotent stem cells the two isoforms sustain different pathways: MBD2a promotes differentiation and its overexpression disrupts pluripotency while MBD2c facilitates reprogramming of fibroblasts (Lu et al., 2014). Moreover this study shows that the $3^{\prime}$ UTR of MBD2a is a direct target of the miR-302, previously reported to promote reprogramming (Subramanyam et al., 2011) via upregulation of NANOG expression and suppression of MBD2 (Lee et al., 2013). These recent findings shed new light on the role of MBD2 in regulating the commitment toward either reprogramming or differentiation, involving the microRNA and splicing factors. Further analysis will be needed to dissect the transcriptional and epigenetic changes in response to deletion of either isoforms, in order to identify specific targets and downstream effectors that might be mediating either lineage commitment or retention of pluripotency.

The role of MBD3 in lineage commitment and pluripotency has recently been at the focus of attention (Yildirim et al., 2011; Reynolds etal., 2012; Whyte etal., 2012). The importance of MBD3 in regulating escape from pluripotency and lineage commitment has been documented in several studies. Early reports described Mbd3 as essential for lineage commitment, since Mbd3 depleted mouse embryonic stem cell failed to differentiate and aberrantly self-renewed independently of leukemia inhibitory factor (LIF), one of the essential factors needed to keep undifferentiated stem cells in culture (Kaji et al., 2006). Recently two independent studies showed that Mbd3 constitutes a gate to full reprogramming and that its depletion together with transduction of the four Yamanaka factors (Oct4, Sox2, Klf4, Myc, all together OSKM) enhances the reprogramming efficiency, consistent with the role of Mbd3 as suppressor of reprogramming (Luo et al., 2013; Rais et al., 2013). However, other findings suggest an opposite role for Mbd3 in facilitating induction of pluripotency (Dos Santos et al., 2014). The authors themselves underline that the differences with respect to previous studies might be due to a different cell system and reprogramming conditions, and that their findings may be context specific. However, reproducibility of previous results seemed to be somewhat challenging, raising more questions than providing answers.

\section{MBPS IN THE ORGANIZATION OF CHROMATIN STRUCTURE}

Several studies have pointed to a role of MBD proteins in the organization of chromatin structure and shaping the local and global epigenome landscape, for instance formation or maintenance of heterochromatic, repressive chromatin (Clouaire and Stancheva, 2008; Fournier et al., 2012), given the presence of an ATP-driven remodeler subunit within the Mi-2/NuRD complex (Wade et al., 1999; Zhang et al., 1999).

Little is known about the impact of MBD2 on chromatin organization in vivo. It has been observed that mouse myoblasts undergoing myogenic differentiation form aggregates of pericentric heterochromatin (chromatin surrounding the centromere) that display increased levels of MeCP2, MBD2, and DNA methylation (Brero etal., 2005; Luo et al., 2009). Overexpression of MBD2 or for that matter MeCP2 induced condensation of densely stained heterochromatin within the nucleus. Interestingly also in the absence of MeCP2 (skeletal muscle tissue derived from MeCP2 knock-out mice), MBD2 overexpression triggered the formation of densely stained repressive chromatin, suggesting some degree of functional redundancy or overlap. The molecular mechanisms behind this aggregation of pericentric chromatin remain unclear. A recent study shows that in human cells ectopic expression of MBD2, but not MBD3, induces heterochromatin compaction (Günther et al., 2013). To resolve the putative role of MBD2 in the formation of higher order chromatin structure it will be important to combine genome-wide localization studies with chromosome conformation capture approaches. A first study along these lines (Shimbo etal., 2013) indeed suggests that MBD3 binding to enhancers results in their closer proximity to promoters and gene bodies because of protein mediated looping.

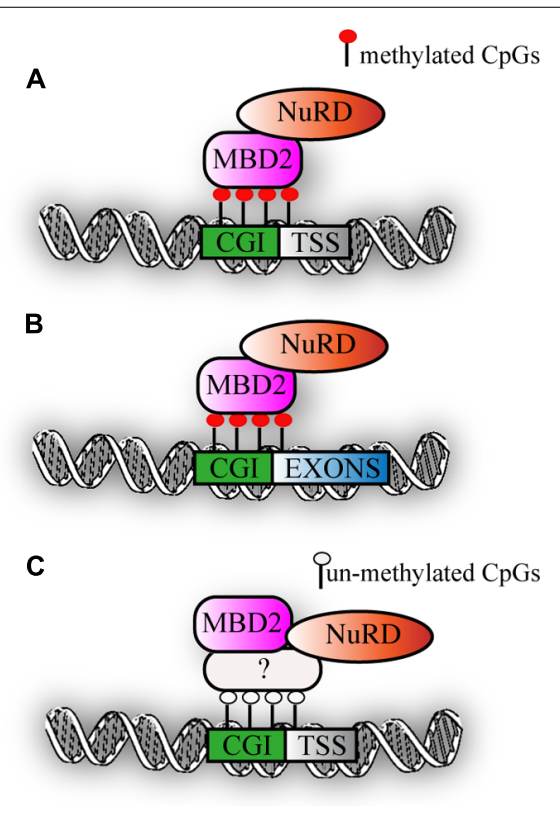

FIGURE 2 | MBD2 binding to chromatin. (A) Schematic representation of MBD2 binding to highly methylated CGI promoters (B) MBD2 binding to highly methylated CGI exons. (C) Subset of MBD2 binds to un-methylated active promoters, this binding depends on the interaction with Mi-2/NuRD complex that might be recruited to chromatin via other, not yet identified factors. 
GENOME-WIDE MBD2 AND MBD3 BINDING SITE ANALYSES

Chromatin immunoprecipitation followed by next generation sequencing, (ChIP-seq) is widely used to determine the binding sites of a protein or transcription factor in a genomewide manner. A substantial amount of literature describes the characterization of MBD2 and MBD3 binding to chromatin at specific loci but only recent studies provided genome-wide maps. ChIP experiments on chromatin regulators, such as Mi-2/NuRD complex, turned out to be quite challenging, presumably because of a combination of factors: low abundancy of the proteins, the transient nature of the chromatin association, short residence time on chromatin and the quality of the antibodies.

Recent genome-wide mapping of MBPs has clearly shown that MBD2 binds to highly methylated, $\mathrm{CpG}$ dense regions in vivo (Baubec et al., 2013). Interestingly, motif analysis did not reveal any specific DNA sequence motif within the MBD2 binding sites and their flanking regions, but highlighted primarily CG richness of the binding sites as the critical factor for binding. In line with this, an intact methyl binding domain is essential to target MBD2 to densely methylated loci. DNA methylation is a prerequisite since binding of MBD2 is lost in cells with triple knock-out for Dnmt1-3a/b, that lack both methylation and hydroxymethylation. MBD2 primarly binds at highly methylated promoters (Günther et al., 2013; Menafra et al., 2014) and secondly exons (Figures 2A,B). Surprisingly, in mouse embryonic stem cells, a correlation between genome-wide MBD2 binding and known components of the $\mathrm{Mi}-2 / \mathrm{NuRD}$ complex such as Mi-2 $\beta$ and Hdac2 was not observed. It should be noted however that the profiles for the two subunits were not performed in parallel (Whyte et al., 2012). Interestingly, a subset of MBD2 binding sites have been uncovered that did not have DNA methylation. The presence of MBD2 at these loci was suggested to be due to its association with the Mi-2/NuRD complex that was recruited to chromatin via other, not yet identified factors (Figure 2C). Indeed, MBD2 binding at such loci was lost when the testis specific MBD2 isoform was expressed that lacks the C-terminus and does not immunoprecipitate any of the known Mi-2/NuRD components. Surprisingly, Baubec et al. also found that MBD2 is recruited to a subset of un-methylated loci that displayed epigenetic marks pointing at active regulatory regions. These data were confirmed in another independent study in which a tagged MBD2 was expressed in human MCF-7 cells. A small fraction of MBD2 binding sites was observed at promoters of genes displaying active histone marks and low gene expression (Menafra et al., 2014). Interestingly, the study from Günther et al. revealed a dichotomy within MBD2 binding to promoters of silent genes and at the same time to exons of actively transcribed genes, suggesting that in the latter case, MBD2 might play a role in splicing. It remains to be elucidated what the effects of MBD2 binding are on transcription and chromatin organization.

Table 1 | Summary of studies characterizing MBD3 binding genome-wide: technical details of the experiments together with findings and algorithm used for the analysis are listed.

\begin{tabular}{|c|c|c|c|c|c|c|c|c|}
\hline Study & Organism & $\begin{array}{l}\text { Cell } \\
\text { type }\end{array}$ & Insert & Antibody & Localization & Chromatin features & $\begin{array}{l}\text { Number of } \\
\text { peaks/enriched } \\
\text { regions }\end{array}$ & $\begin{array}{l}\text { Algorithm } \\
\text { used for } \\
\text { analysis }\end{array}$ \\
\hline $\begin{array}{l}\text { Yildirim et al. } \\
\text { (2011) }\end{array}$ & Mouse & ES & $\begin{array}{l}\text { NA } \\
\text { (endogenous) }\end{array}$ & $\begin{array}{l}\text { Mix of } \\
\text { (ab3755) and } \\
\text { Bethyl } \\
\text { (A302-528A) }\end{array}$ & $\begin{array}{l}\text { Downstream } \\
\text { TSS }\end{array}$ & Hydroxy-methyl, Tet1 & NA & NA \\
\hline $\begin{array}{l}\text { Baubec et al. } \\
\text { (2013) }\end{array}$ & Mouse & ES & $\begin{array}{l}\text { MBD3 } \\
\text { biotinylated }\end{array}$ & $\begin{array}{l}\text { Streptavidin } \\
\text { beads }\end{array}$ & $\begin{array}{l}\text { Unmethylated } \\
\text { regions }\end{array}$ & $\begin{array}{l}\text { DNasel, H3K4me1, } \\
\text { and H3K27ac }\end{array}$ & NA & $\begin{array}{l}\text { Enrichment } \\
\text { over input in a } \\
1 \mathrm{~kb} \text { sliding } \\
\text { window }\end{array}$ \\
\hline $\begin{array}{l}\text { Günther et al. } \\
\text { (2013) }\end{array}$ & Human & HeLa & MBD3-V5 & $\begin{array}{l}\text { V5 agarose } \\
\text { (Sigma Aldrich } \\
\text { A7345) }\end{array}$ & $\begin{array}{l}\text { CpG rich, } \\
\text { unmethylated } \\
\text { promoters }\end{array}$ & $\begin{array}{l}\text { H3K4me2/3; H3K9ac; } \\
\text { DNAse 1; FAIRE }\end{array}$ & 490 & Peak-ranger \\
\hline $\begin{array}{l}\text { Shimbo et al. } \\
\text { (2013) }\end{array}$ & Human & MCF-7 & $\begin{array}{l}\text { NA } \\
\text { (endogenous) }\end{array}$ & Ab91458 & $\begin{array}{l}\text { Promoters, } \\
\text { gene bodies } \\
\text { and enhancers } \\
\text { of active genes }\end{array}$ & $\begin{array}{l}\text { Five patterns:mainly } \\
\text { H3K27ac (not TSS) } \\
\text { and H3K4me3 TSS }\end{array}$ & 35165 & SICER \\
\hline $\begin{array}{l}\text { Shimbo et al. } \\
\text { (2013) }\end{array}$ & Human & $\begin{array}{l}\text { MDA- } \\
231\end{array}$ & $\begin{array}{l}\text { NA } \\
\text { (endogenous) }\end{array}$ & Ab91458 & $\begin{array}{l}\text { Promoters, } \\
\text { gene bodies } \\
\text { and enhancers } \\
\text { of active genes }\end{array}$ & $\begin{array}{l}\text { Five patterns:mainly } \\
\text { H3K27ac (not TSS) } \\
\text { and H3K4me3 TSS }\end{array}$ & 23880 & SICER \\
\hline
\end{tabular}


Identification of genome-wide binding sites and functional analyses of MBD3 have been performed in mouse (Yildirim et al., 2011; Baubec et al., 2013) and human cells (Günther et al., 2013; Shimbo et al., 2013) reaching different conclusions. Yildirim et al. reported that $\mathrm{MBD} 3$ binds just downstream of the transcription start site (TSS) of CpG-rich promoters marked by hydroxymethylation. Baubec et al. found, however, that MBD3 binds to active regulatory regions (enhancers) independent of $\mathrm{CpG}$ density and independent of their methylation or hydroxymethylation status, since binding was maintained in Dnmt1/3a/3b triple knock-out embryonic stem cells. These data question the validity of the binding of MBD3 to hydroxymethylated DNA, which was further underpinned by DNA pull-downs followed by MS analysis (Spruijt et al., 2013), which did reveal hydroxymethylation specific readers but in which MBD3 was not detected.

Independent studies in human cells (Günther et al., 2013; Shimbo et al., 2013) both suggested that MBD3 is localized at CpG rich promoters of active genes, but while Günther et al. (2013) showed that it mainly binds promoters, Shimbo and coworkers suggested a more complex regulation of both active and silent genes. They showed that a fraction of MBD3 binds at enhancers that are in physical proximity to promoters and gene bodies in three-dimensional space and hence are picked up in the assay. Since these data have been generated by different groups, using different antibodies, cell systems, and sequencing analysis pipelines (see Table 1, for a summary of the different studies), re-analysis of the data with a common approach may resolve some of the major and minor discrepancies. Interestingly, the genome-wide binding map of MBD3 correlates to some extend with that of another Mi-2/NuRD component, Mi$2 \beta$, implying partial co-recruitment of these two subunits on chromatin. Further studies will be needed to assess whether this interaction is necessary for $\mathrm{Mi}-2 / \mathrm{NuRD}$ to bind the chromatin and whether MBD3 depletion would result in loss of Mi-2 $\beta$ binding or vice versa. Similarly as reported for MBD2, depletion of MBD3 in human (Günther et al., 2013) and mouse cells (Yildirim et al., 2011) resulted in alteration of gene expression for only a small number of genes and in both cases, the transcriptional changes are rather mild.

Taken together, the above findings suggest that MBD3 binds CpG-rich active promoters and enhancers that are not DNA methylated (Figure 3). The downstream functional consequence of MBD3 binding has still to be elucidated.

\section{CONCLUDING REMARKS}

Since its discovery in 1975, DNA methylation has been one of the best studied epigenetic marks and the readers of DNA methylation that translate the signal of methylated DNA into a function or activity have obtained a lot of attention. MBD2 and MBD3 are two very similar proteins, which are interchangeable structural parts of the Mi-2/NuRD complex and share many common subunits. Nevertheless, they appear to perform distinct functions and to differ completely in their ability to bind methylated DNA. The emerging picture is that MBD2 binds to CpG-rich, densely methylated DNA in vivo, with an apparent but not understood preference for promoter regions. A minor fraction of MBD2 is present at promoters that bear active epigenetic marks and are not

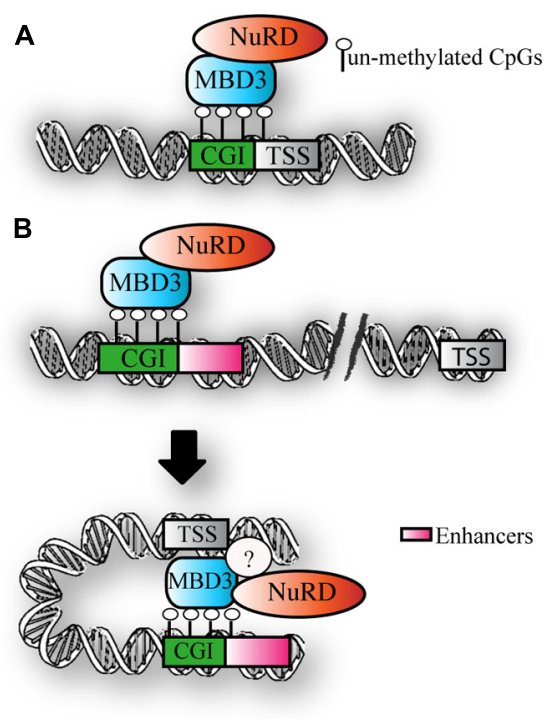

FIGURE 3 | MBD3 binding to chromatin. (A) Schematic representation of MBD3 binding to unmethylated CGI promoters (B) MBD3 binding to unmethylated enhancers, that are in physical proximity to promoters in three-dimensional space. The question mark indicates the possible presence of other subunits involved in this association.

methylated. This is the only fraction of binding sites depending on the interaction with $\mathrm{Mi}-2 / \mathrm{NuRD}$, suggesting that MBD2 might also have a function independent of $\mathrm{Mi}-2 / \mathrm{NuRD}$. Recruitment of Mi-2/NuRD might also depend on subunits other than MBD2 such as GATAD2A-B or MTA1-2 that is reported to directly bind the histone $\mathrm{H} 3$ tail in vitro (Robertson and Jones, 2000; Wu et al., 2013). Supporting in vivo data is currently not available. Therefore additional biochemical studies followed by in vivo evidence, for example by ChIP-seq, should be performed to assess whether MBD2 exists in distinct complexes and can bind to unmethylated regions independent of $\mathrm{Mi}-2 / \mathrm{NuRD}$. MBD3 binds $\mathrm{CpG}$-rich, unmethylated active promoters and enhancers. One of the burning questions is how $\mathrm{MBD} 3 / \mathrm{NuRD}$ is recruited to its genomic binding sites. Does MBD3 play a role, are other subunits important or is the association based on transient protein-mediated interactions? What seems clear is that MBD3 plays an important role in lineage commitment.

The biological functions of MBD2 and MBD3 remain an open question; whether and how they modulate transcriptional activity and chromatin structure. The recent coupling of chromosome conformation capture technologies with deep-sequencing might provide an interesting angle to look for possible participation of $\mathrm{MBD} 2$ in long range interactions, a model proposed for MBD3 but not yet addressed in a genome-wide fashion. Even after decades of research, DNA methylation readers are still hiding their true nature, raising puzzling but at the same time intriguing questions for further research.

\section{REFERENCES}

Amir, R. E., Van Den Veyver, I. B., Wan, M., Tran, C. Q., Francke, U., and Zoghbi, H. Y. (1999). Rett syndrome is caused by mutations in X-linked MECP2, encoding methyl-CpG-binding protein 2. Nat. Genet. 23, 185-188. doi: 10.1038/13810 
Ariel, M., Robinson, E., Mccarrey, J. R., and Cedar, H. (1995). Gamete-specific methylation correlates with imprinting of the murine Xist gene. Nat. Genet. 9 , 312-315. doi: 10.1038/ng0395-312

Barr, H., Hermann, A., Berger, J., Tsai, H. H., Adie, K., Prokhortchouk, A., et al. (2007). Mbd2 contributes to DNA methylation-directed repression of the Xist gene. Mol. Cell. Biol. 27, 3750-3757. doi: 10.1128/MCB.02204-06

Baubec, T., Ivánek, R., Lienert, F., and Schübeler, D. (2013). Methylation-dependent and -independent genomic targeting principles of the MBD protein family. Cell 153, 480-492. doi: 10.1016/j.cell.2013.03.011

Baymaz, H. I., Fournier, A., Laget, S., Ji, Z., Jansen, P. W., Smits, A. H., etal. (2014). MBD5 and MBD6 interact with the human PR-DUB complex through their methyl-CpG-binding domain. Proteomics 14, 2179-2189. doi: 10.1002/pmic.201400013

Bednarik, D. P., Duckett, C., Kim, S. U., Perez, V. L., Griffis, K., Guenthner, P. C., et al. (1991). DNA CpG methylation inhibits binding of NF-kappa B proteins to the HIV-1 long terminal repeat cognate DNA motifs. New Biol. 3, 969-976.

Bird, A. P. (1986). CpG-rich islands and the function of DNA methylation. Nature 321, 209-213. doi: 10.1038/321209a0

Brackertz, M., Boeke, J., Zhang, R., and Renkawitz, R. (2002). Two highly related p66 proteins comprise a new family of potent transcriptional repressors interacting with MBD2 and MBD3. J. Biol. Chem. 277, 40958-40966. doi: 10.1074/jbc.M207467200

Brero, A., Easwaran, H. P., Nowak, D., Grunewald, I., Cremer, T., Leonhardt, H., et al. (2005). Methyl CpG-binding proteins induce large-scale chromatin reorganization during terminal differentiation. J. Cell Biol. 169, 733-743. doi: 10.1083/jcb.200502062

Chahrour, M., Jung, S. Y., Shaw, C., Zhou, X., Wong, S. T., Qin, J., et al. (2008). MeCP2, a key contributor to neurological disease, activates and represses transcription. Science 320, 1224-1229. doi: 10.1126/science.1153252

Clouaire, T., and Stancheva, I. (2008). Methyl-CpG binding proteins: specialized transcriptional repressors or structural components of chromatin? Cell. Mol. Life Sci. 65, 1509-1522. doi: 10.1007/s00018-008-7324-y

Comb, M., and Goodman, H. M. (1990). CpG methylation inhibits proenkephalin gene expression and binding of the transcription factor AP-2. Nucleic Acids Res. 18, 3975-3982. doi: 10.1093/nar/18.13.3975

Cortellino, S., Xu, J., Sannai, M., Moore, R., Caretti, E., Cigliano, A., et al (2011). Thymine DNA glycosylase is essential for active DNA demethylation by linked deamination-base excision repair. Cell 146, 67-79. doi: 10.1016/j.cell.2011. 06.020

Dos Santos, R. L., Tosti, L., Radzisheuskaya, A., Caballero, I. M., Kaji, K., Hendrich, B., et al. (2014). MBD3/NuRD facilitates induction of pluripotency in a contextdependent manner. Cell Stem Cell 15, 102-110. doi: 10.1016/j.stem.2014.04.019

Feinberg, A. P., and Vogelstein, B. (1983). Hypomethylation distinguishes genes of some human cancers from their normal counterparts. Nature 301, 89-92. doi: 10.1038/301089a0

Fournier, A., Sasai, N., Nakao, M., and Defossez, P. A. (2012). The role of methylbinding proteins in chromatin organization and epigenome maintenance. Brief Funct. Genomics 11, 251-264. doi: 10.1093/bfgp/elr040

Fujita, N., Watanabe, S., Ichimura, T., Tsuruzoe, S., Shinkai, Y., Tachibana, M., et al. (2003). Methyl-CpG binding domain 1 (MBD1) interacts with the Suv39h1-HP1 heterochromatic complex for DNA methylation-based transcriptional repression. J. Biol. Chem. 278, 24132-24138. doi: 10.1074/jbc.M302283200

Gnanapragasam, M. N., Scarsdale, J. N., Amaya, M. L., Webb, H. D., Desai, M. A., Walavalkar, N. M., et al. (2011). p66 $\alpha$-MBD2 coiled-coil interaction and recruitment of Mi-2 are critical for globin gene silencing by the MBD2-NuRD complex. Proc. Natl. Acad. Sci. U.S.A. 108, 7487-7492. doi: 10.1073/pnas.1015341108

Günther, K., Rust, M., Leers, J., Boettger, T., Scharfe, M., Jarek, M., et al. (2013). Differential roles for MBD2 and MBD3 at methylated CpG islands, active promoters and binding to exon sequences. Nucleic Acids Res. 41, 3010-3021. doi: 10.1093/nar/gkt035

He, Y. F., Li, B. Z., Li, Z., Liu, P., Wang, Y., Tang, Q., et al. (2011). Tet-mediated formation of 5-carboxylcytosine and its excision by TDG in mammalian DNA. Science 333, 1303-1307. doi: 10.1126/science.1210944

Hendrich, B., and Bird, A. (1998). Identification and characterization of a family of mammalian methyl-CpG binding proteins. Mol. Cell. Biol. 18, 6538-6547.

Hendrich, B., Guy, J., Ramsahoye, B., Wilson, V. A., and Bird, A. (2001a). Closely related proteins $\mathrm{MBD} 2$ and $\mathrm{MBD} 3$ play distinctive but interacting roles in mouse development. Genes Dev. 15, 710-723. doi: 10.1101/gad.194101
Hendrich, B., Guy, J., Ramsahoye, B., Wilson, V. A., and Bird, A. (2001b). Closely related proteins MBD2 and MBD3 play distinctive but interacting roles in mouse development. Genes Dev. 15, 710-723. doi: 10.1101/gad.194101

Holliday, R. (1989). DNA methylation and epigenetic mechanisms. Cell Biophys. 15, 15-20. doi: 10.1007/BF02991575

Holliday, R., and Pugh, J. E. (1975). DNA modification mechanisms and gene activity during development. Science 187, 226-232. doi: 10.1126/science.1111098

Hutchins, A. S., Mullen, A. C., Lee, H. W., Sykes, K. J., High, F. A., Hendrich, B. D., et al. (2002). Gene silencing quantitatively controls the function of a developmental trans-activator. Mol. Cell. 10, 81-91. doi: 10.1016/S1097-2765(02)00564-6

Iguchi-Ariga, S. M., and Schaffner, W. (1989). CpG methylation of the cAMPresponsive enhancer/promoter sequence TGACGTCA abolishes specific factor binding as well as transcriptional activation. Genes Dev. 3, 612-619. doi: 10.1101/gad.3.5.612

Ito, S., Shen, L., Dai, Q., Wu, S. C., Collins, L. B., Swenberg, J. A., et al. (2011). Tet proteins can convert 5-methylcytosine to 5-formylcytosine and 5-carboxylcytosine. Science 333, 1300-1303. doi: 10.1126/science.1210597

Jones, M. H., Hamana, N., Nezu, J., and Shimane, M. (2000). A novel family of bromodomain genes. Genomics 63, 40-45. doi: 10.1006/geno.1999.6071

Kaji, K., Caballero, I. M., MacLeod, R., Nichols, J., Wilson, V. A., and Hendrich, B. (2006). The NuRD component Mbd3 is required for pluripotency of embryonic stem cells. Nat. Cell Biol. 8, 285-292. doi: 10.1038/ncb1372

Kangaspeska, S., Stride, B., Metivier, R., Polycarpou-Schwarz, M., Ibberson, D., Carmouche, R. P., et al. (2008). Transient cyclical methylation of promoter DNA. Nature 452, 112-115. doi: 10.1038/nature06640

Klose, R. J., and Bird, A. P. (2006). Genomic DNA methylation: the mark and its mediators. Trends Biochem. Sci. 31, 89-97. doi: 10.1016/j.tibs.2005.12.008

Kovesdi, I., Reichel, R., and Nevins, J. R. (1987). Role of an adenovirus E2 promoter binding factor in E1A-mediated coordinate gene control. Proc. Natl. Acad. Sci. U.S.A. 84, 2180-2184. doi: 10.1073/pnas.84.8.2180

Kransdorf, E. P., Wang, S. Z., Zhu, S. Z., Langston, T. B., Rupon, J. W., and Ginder, G. D. (2006). MBD2 is a critical component of a methyl cytosine-binding protein complex isolated from primary erythroid cells. Blood 108, 2836-2845. doi: 10.1182/blood-2006-04-016394

Kriaucionis, S., and Heintz, N. (2009). The nuclear DNA base 5hydroxymethylcytosine is present in Purkinje neurons and the brain. Science 324, 929-930. doi: 10.1126/science.1169786

Laget, S., Joulie, M., Le Masson, F., Sasai, N., Christians, E., Pradhan, S., et al. (2010). The human proteins MBD5 and MBD6 associate with heterochromatin but they do not bind methylated DNA. PLOS ONE 5:e11982. doi: 10.1371/journal.pone.0011982

Le Guezennec, X., Vermeulen, M., Brinkman, A. B., Hoeijmakers, W. A., Cohen, A., Lasonder, E., et al. (2006). MBD2/NuRD and MBD3/NuRD, two distinct complexes with different biochemical and functional properties. Mol. Cell. Biol. 26, 843-851. doi: 10.1128/MCB.26.3.843-851.2006

Lee, M. R., Prasain, N., Chae, H. D., Kim, Y. J., Mantel, C., Yoder, M. C., et al. (2013). Epigenetic regulation of NANOG by miR-302 cluster-MBD2 completes induced pluripotent stem cell reprogramming. Stem Cells 31, 666-681. doi: 10.1002/stem.1302

Lewis, J. D., Meehan, R. R., Henzel, W. J., Maurer-Fogy, I., Jeppesen, P., Klein, F., et al. (1992). Purification, sequence, and cellular localization of a novel chromosomal protein that binds to methylated DNA. Cell 69, 905-914. doi: 10.1016/00928674(92)90610-O

Lu, Y., Loh, Y. H., Li, H., Cesana, M., Ficarro, S. B., Parikh, J. R., et al. (2014). Alternative splicing of MBD2 supports self-renewal in human pluripotent stem cells. Cell Stem Cell 15, 92-101. doi: 10.1016/j.stem.2014.04.002

Luo, M., Ling, T., Xie, W., Sun, H., Zhou, Y., Zhu, Q., et al. (2013). NuRD blocks reprogramming of mouse somatic cells into pluripotent stem cells. Stem Cells 31, 1278-1286. doi: 10.1002/stem.1374

Luo, S. W., Zhang, C., Zhang, B., Kim, C. H., Qiu, Y. Z., Du, Q. S., et al. (2009). Regulation of heterochromatin remodelling and myogenin expression during muscle differentiation by FAK interaction with MBD2. EMBO J. 28, 2568-2582. doi: 10.1038/emboj.2009.178

Marhold, J., Kramer, K., Kremmer, E., and Lyko, F. (2004). The Drosophila MBD2/3 protein mediates interactions between the MI-2 chromatin complex and CpT/Amethylated DNA. Development 131, 6033-6039. doi: 10.1242/dev.01531

Martin Caballero, I., Hansen, J., Leaford, D., Pollard, S., and Hendrich, B. D. (2009). The methyl-CpG binding proteins Mecp2, Mbd2 and Kaiso are dispensable for 
mouse embryogenesis, but play a redundant function in neural differentiation. PLoS ONE 4:e4315. doi: 10.1371/journal.pone.0004315

Menafra, R., Brinkman, A. B., Matarese, F., Franci, G., Bartels, S. J., Nguyen, L., et al. (2014). Genome-wide binding of MBD2 reveals strong preference for highly methylated loci. PLoS ONE 9:e99603. doi: 10.1371/journal.pone.0099603

Metivier, R., Gallais, R., Tiffoche, C., Le Peron, C., Jurkowska, R. Z., Carmouche, R. P., et al. (2008). Cyclical DNA methylation of a transcriptionally active promoter. Nature 452, 45-50. doi: 10.1038/nature06544

Moretti, P., and Zoghbi, H. Y. (2006). MeCP2 dysfunction in Rett syndrome and related disorders. Curr. Opin. Genet. Dev. 16, 276-281. doi: 10.1016/j.gde.2006.04.009

Nan, X., Meehan, R. R., and Bird, A. (1993). Dissection of the methyl-CpG binding domain from the chromosomal protein MeCP2. Nucleic Acids Res. 21, 4886-4892. doi: $10.1093 /$ nar/21.21.4886

Nan, X., Ng, H. H., Johnson, C. A., Laherty, C. D., Turner, B. M., Eisenman, R. N., et al. (1998). Transcriptional repression by the methyl-CpG-binding protein MeCP2 involves a histone deacetylase complex. Nature 393, 386-389. doi: $10.1038 / 30764$

Prendergast, G. C., Lawe, D., and Ziff, E. B. (1991). Association of Myn, the murine homolog of max, with c-Myc stimulates methylation-sensitive DNA binding and ras cotransformation. Cell 65, 395-407. doi: 10.1016/0092-8674(91)90457-A

Rais, Y., Zviran, A., Geula, S., Gafni, O., Chomsky, E., Viukov, S., et al. (2013). Deterministic direct reprogramming of somatic cells to pluripotency. Nature 502, 65-70. doi: 10.1038/nature 12587

Reynolds, N., Latos, P., Hynes-Allen, A., Loos, R., Leaford, D., O’Shaughnessy, A., et al. (2012). NuRD suppresses pluripotency gene expression to promote transcriptional heterogeneity and lineage commitment. Cell Stem Cell 10, 583 594. doi: 10.1016/j.stem.2012.02.020

Robertson, K. D., and Jones, P. A. (2000). DNA methylation: past, present and future directions. Carcinogenesis 21, 461-467. doi: 10.1093/carcin/21.3.461

Saito, M., and Ishikawa, F. (2002). The mCpG-binding domain of human MBD3 does not bind to mCpG but interacts with NuRD/Mi2 components HDAC1 and MTA2. J. Biol. Chem. 277, 35434-35439. doi: 10.1074/jbc.M203455200

Sarraf, S. A., and Stancheva, I. (2004). Methyl-CpG binding protein MBD1 couples histone $\mathrm{H} 3$ methylation at lysine 9 by SETDB1 to DNA replication and chromatin assembly. Mol. Cell. 15, 595-605. doi: 10.1016/j.molcel.2004.06.043

Schultz, D. C., Ayyanathan, K., Negorev, D., Maul, G. G., and Rauscher, F. J. III. (2002). SETDB1: a novel KAP-1-associated histone H3, lysine 9-specific methyltransferase that contributes to HP1-mediated silencing of euchromatic genes by KRAB zinc-finger proteins. Genes Dev. 16, 919-932. doi: 10.1101/gad. 973302

Shimbo, T., Du, Y., Grimm, S. A., Dhasarathy, A., Mav, D., Shah, R. R., et al. (2013). MBD3 localizes at promoters, gene bodies and enhancers of active genes. PLoS Genet. 9:e1004028. doi: 10.1371/journal.pgen.1004028

Spruijt, C. G., Bartels, S. J., Brinkman, A. B., Tjeertes, J. V., Poser, I., Stunnenberg, H. G., et al. (2010). CDK2AP1/DOC-1 is a bona fide subunit of the Mi-2/NuRD complex. Mol. Biosyst. 6, 1700-1706. doi: 10.1039/c004108d
Spruijt, C. G., Gnerlich, F., Smits, A. H., Pfaffeneder, T., Jansen, P. W., Bauer, C., et al. (2013). Dynamic readers for 5-(hydroxy)methylcytosine and its oxidized derivatives. Cell 152, 1146-1159. doi: 10.1016/j.cell.2013.02.004

Subramanyam, D., Lamouille, S., Judson, R. L., Liu, J. Y., Bucay, N., Derynck, R., et al. (2011). Multiple targets of miR-302 and miR-372 promote reprogramming of human fibroblasts to induced pluripotent stem cells. Nat. Biotechnol. 29, 443-448. doi: 10.1038/nbt.1862

Tahiliani, M., Koh, K. P., Shen, Y., Pastor, W. A., Bandukwala, H., Brudno, Y., et al. (2009). Conversion of 5-methylcytosine to 5-hydroxymethylcytosine in mammalian DNA by MLL partner TET1. Science 324, 930-935. doi: $10.1126 /$ science. 1170116

Wade, P. A., Gegonne, A., Jones, P. L., Ballestar, E., Aubry, F., and Wolffe, A. P. (1999). Mi-2 complex couples DNA methylation to chromatin remodelling and histone deacetylation. Nat. Genet. 23, 62-66. doi: 10.1038/12664

Whyte, W. A., Bilodeau, S., Orlando, D. A., Hoke, H. A., Frampton, G. M., Foster, C. T., et al. (2012). Enhancer decommissioning by LSD1 during embryonic stem cell differentiation. Nature 482, 221-225. doi: 10.1038/nature10805

Wu, M., Wang, L., Li, Q., Li, J., Qin, J., and Wong, J. (2013). The MTA family proteins as novel histone $\mathrm{H} 3$ binding proteins. Cell Biosci. 3:1. doi: 10.1186/2045-3701-3-1

Wutz, A., Smrzka, O. W., Schweifer, N., Schellander, K., Wagner, E. F., and Barlow, D. P. (1997). Imprinted expression of the Igf2r gene depends on an intronic CpG island. Nature 389, 745-749. doi: 10.1038/39631

Yildirim, O., Li, R., Hung, J. H., Chen, P. B., Dong, X., Ee, L. S., et al. (2011). Mbd3/NURD complex regulates expression of 5-hydroxymethylcytosine marked genes in embryonic stem cells. Cell 147, 1498-1510. doi: 10.1016/j.cell.2011.11.054

Zhang, Y., Ng, H. H., Erdjument-Bromage, H., Tempst, P., Bird, A., and Reinberg, D. (1999). Analysis of the NuRD subunits reveals a histone deacetylase core complex and a connection with DNA methylation. Genes Dev. 13, 1924-1935. doi: 10.1101/gad.13.15.1924

Conflict of Interest Statement: The authors declare that the research was conducted in the absence of any commercial or financial relationships that could be construed as a potential conflict of interest.

Received: 03 October 2014; paper pending published: 29 October 2014; accepted: 21 November 2014; published online: 09 December 2014.

Citation: Menafra R and Stunnenberg HG (2014) MBD2 and MBD3: elusive functions and mechanisms. Front. Genet. 5:428. doi: 10.3389/fgene.2014.00428

This article was submitted to Epigenomics and Epigenetics, a section of the journal Frontiers in Genetics.

Copyright (c) 2014 Menafra and Stunnenberg. This is an open-access article distributed under the terms of the Creative Commons Attribution License (CC BY). The use, distribution or reproduction in other forums is permitted, provided the original author(s) or licensor are credited and that the original publication in this journal is cited, in accordance with accepted academic practice. No use, distribution or reproduction is permitted which does not comply with these terms. 